\title{
The Modernist Novel in its Contemporaneity
}

\author{
Pamela L. Caughie \\ Loyola University Chicago, pcaughi@luc.edu
}

Follow this and additional works at: https://ecommons.luc.edu/english_facpubs

Part of the English Language and Literature Commons

\section{Recommended Citation}

This Book Chapter is brought to you for free and open access by the Faculty Publications and Other Works by Department at Loyola eCommons. It has been accepted for inclusion in English: Faculty Publications and Other Works by an authorized administrator of Loyola eCommons. For more information, please contact ecommons@luc.edu.

\section{(c) (1) $(9)$}

This work is licensed under a Creative Commons Attribution-Noncommercial-No Derivative Works 3.0 License. (C) Cambridge University Press, 2015 
CHAPTER I 8

\title{
The Modernist Novel in Its Contemporaneity
}

\author{
Pamela L. Caughie
}

Nothing is less real than realism. Georgia O'Keeffe

When Georgia O'Keeffe sought to convey the spectacle of a flower in bloom, she found an affective equivalent in the quintessential modernist structure, the skyscraper: "And when the bloom came out, I felt as though a skyscraper had gone up overnight." When Virginia Woolf wanted to capture the rapid changes of bodily sensations that comprise the modern woman, she found her figure in the "raging torrent" of objects and impressions that one experiences when motoring fast through London and created the verbal equivalent of an abstract modernist collage: "Vast blue blocks of building rose into the air; the red cowls of chimneys were spotted irregularly across the sky; the road shone like silver-headed nails; omnibuses bore down upon her with sculptured white-faced drivers; she noticed sponges, birdcages, boxes of green American cloth." ${ }^{2}$ When Gertrude Stein needed a concrete example to distinguish the "time-sense" of the twentieth century from that of the nineteenth, she turned to the Ford assembly line: "instead of having the feeling of beginning at one end and ending at another, [the twentieth century] had the conception of assembling the whole thing out of its parts." 3 The famed difficulty of modernist art, often attributed to the radical formal experimentalism of avant-garde artists, actually hails from more mundane circumstances: everyday life in the early twentieth century. Through the writings of Gertrude Stein, Virginia Woolf, and Nella Larsen, this chapter considers the temporality of the now, the modernist novel in its contemporaneity, to show how the ambient environment of daily life takes shape in, and shapes, the modernist novel. 
In "How Writing Is Written," a lecture delivered at the Choate School during her American tour of 1934-35, Gertrude Stein counters the notion of the modernist artist as avant-garde in the sense of "ahead of his time" with a characteristically simple, if not simplistic, declarative statement: "everybody is contemporary with his period" ("How" 488). This homiletic remark has profound implications for our understanding of the modernist novel. Long revered, and feared, for its celebrated difficulty, the modernist novel is in many ways down to earth. Replete with the detritus of everyday life, it strives to capture the material reality and sensate experience of the early twentieth century and, in the process, renders realism, the representation of life in its social and historical specificity, a bit strange. For our perceptual habits, Stein says, always languish behind the times. "In the things concerning art and literature," she tells her audience, "you will want the things you know" ("How" 488-89), and what we know, as opposed to what we sense, depends on artistic and literary conventions that no longer strike us as conventions. The "accepted convention of what things looked like," 4 as Roger Fry puts it in "An Essay in Aesthetics" (1909), acts as a drag upon the senses. The "persistent drag" of habit, Stein argues, made it difficult for readers to grasp the contemporaneity of the modernist novel, which in turn made it appear to be "ahead of its time" when actually its contemporary readers' perceptual equipment was outmoded.

From Henry James's retort to his critics in "The Art of Fiction" (I884), in which he affirms that a novel attempts to give an "air of reality," yet maintains that that reality exists in the minute examination of consciousness and perception rather than in plot-driven events; to Fry's claim in "An Essay in Aesthetics" that "ordinary people have almost no idea of what things really look like," so influenced are they by past aesthetic conventions that they are incapable of comparing art to nature, ironically the very test of a good painting; to Virginia Woolf's concession in "Mr. Bennett and Mrs. Brown" (1924) that character is central to the novel but that human character changed circa December I9I0, even though the public still expects to see the hot water bottle to believe in an old woman like Mrs. Brown; to Fredric Jameson's declaration in 
Postmodernism, or the Cultural Logic of Late Capitalism (I99I) that "we do not yet possess the perceptual equipment" to navigate postmodern hyperspace "because our perceptual habits were formed in ... the space of high modernism" - each generation of artists and writers for over a century has proclaimed that the perceptual tools of the previous generation impede our apprehension of the contemporary scene. In this respect, they are all modernists, emphasizing the importance of mediation.

With the waning of a strictly formalist analysis of literature and the rise of cultural criticism in the I980s and I990s, modernism began to be understood from the bottom up, so to speak. Studying modernism in the 1960 s and 1970 , one received the impression that modernist artists were removed from, if not hostile to, mass culture. Clive Bell's opposition to jazz, Theodor Adorno's critique of the culture industry, Woolf's class elitism all came to emblemize a modernist sensibility. Aesthetic modernism - or at least "a certain austere image of 'high modernism', as advanced by the New Critics" 7 - privileged stylistic innovation and insisted on the autonomy of the artwork to the extent that it remained aloof from everyday social life. More recent scholarship, now referred to as the new modernist studies, has insisted on modernism's intimate relationship to mass culture, specifically the changing social, economic, and technological conditions of late modernity. ${ }^{8} \mathrm{New}$ sensorial experiences - the perspectival shift produced by a skyscraper, the shrinkage of spatial distance achieved by a radio broadcast, the minute examination of an object through a filmic close-up, the reflexive gaze of a mannequin in a shop window - made writers and audiences alike more aware of mediation, creating the ironic distance and self-consciousness that has come to characterize the modernist novel. "The inevitable mediation of experience," proclaims Michael North, "has also become inescapably obvious, so much so that self-consciousness about it has to be considered as a sociopolitical fact." 9 The modernist novel does more than mediate readers' experiences of contemporary life; it acknowledges modern lived experience as itself mediated. Modernism is, for North, "a play on the artificial mediation so prominent in modern life." ${ }^{\circ}$ 
What Walter Benjamin says of film is true as well of the modernist novel: "By close-ups of the things around us, by focusing on hidden details of familiar objects, by exploring commonplace milieus under the ingenious guidance of the camera, the film, on the one hand, extends our comprehension of the necessities which rule our lives; on the other hand, it manages to assure us of an immense and unexpected field of action." "I The modernist novel immerses its readers in the familiar and the commonplace, providing an affective equivalent of everyday life, but more importantly, it immerses readers in the moment, "an immense and unexpected field of action," in the instant when the perceptual apparatus is catching up with new media and new forms of mediation. This function can best be illustrated by Woolf's Jacob's Room, published in that defining year for modernism, 1922.

The kind of synchrony Stein identifies with the twentieth century through the analogy of the assembly line is evident in Woolf's Jacob's Room. The novel begins abruptly - "'So of course,' wrote Betty Flanders, pressing her heels rather deeper in the sand, 'there was nothing for it but to leave" 12 - and consists of scenes juxtaposed in a collagelike structure, with no narrative agency to orient the reader to the time or place setting of the scenes. Although the novel moves chronologically, from Jacob's boyhood to his untimely death, it does not flow linearly; it jumps, cuts, skips. The end of the first chapter, with its close-up of a crab in a bucket, and the last scene of the novel, where Mrs. Flanders holds up a pair of Jacob's old shoes, are both framed moments, film stills. They do not lead to anything; they are what they are: a crab in a bucket, a pair of shoes. The "realist' pathos"13 of those shoes, a metonym for the departed Jacob, stops short of sentimentality as our vision is drawn to the mundane. The shoes and the bucket are familiar objects whose reality has been significantly altered in the modernist era by technologies like the camera. The natural perception of the nineteenth century has given way to the photographic perception of the twentieth, an insight artist Thomas Lawson encapsulates: "The photograph is the modern world." "I4 Jacob's Room abounds with such photographic moments. In this novel, the emphasis is on the mediation of the world. Its 
narrative structure and point of view are filmic. In chapter four, for example, Mrs. Pascoe is described standing at her garden gate, "looking now to the right, now to the left" $(J R 55)$. Why narrate that? When Jacob visits the Erechtheum, whose caryatid figure on the-left reminds him of Sandra Wentworth Williams, the narrator tells us, "He looked at her, then looked away. He looked at her, then looked away" ( $\left.J R \mathrm{I}_{5} \mathrm{I}\right)$. Why repeat that? Because that is the kind of thing film captures, the way film works. "The cinema goes on the same principle," writes Stein: "each picture is just infinitesimally different from the one before." I5 It's not a question of the novel imitating film; rather, the modernist novel conveys the perspectival shift, a new principle of selection, driving new technologies.

In "Mr. Bennett and Mrs. Brown," a defense of character in Jacob's Room, Woolf argues that what is true about a character is what is accepted as being true within the narrative conventions of the time. In using Mrs. Brown to illustrate a change in the conception of character in fiction in the modernist era, Woolf shows that the old view of character comes from a certain type of narrative. For the Edwardians like Arnold Bennett, character had to do with the "fabric of things": with houses, clothing, families, property - that is, it was fixed, bounded, empirical. ${ }^{16}$ For Woolf, in contrast, a "real" character does not mean a character who is "life-like" in this way; rather, a real character is one who makes us see things through its eyes, one who mediates our relation to lived experience ("Bennett" 103). Woolf's essay is less a critique of social reality than a critique of certain literary conventions through which we have learned to negotiate that reality. Realists draw boundaries, identify properties; they are empirically inclined. Modernists concern themselves with social space, with relations; they are structurally inclined. In writing her story of Mrs. Brown (as earlier in writing her novel of Jacob), Woolf tells us "how keenly [she] felt the lack of a convention, and how serious a matter it is when the tools of one generation are useless for the next" ("Bennett" III). Often referred to as Woolf's aesthetic manifesto, "Mr. Bennett and Mrs. Brown" invites us to "[ $t]$ olerate the spasmodic, the obscure, the fragmentary, the failure" ("Bennett" I19) because we are living in the moment when one set of 
conventions is in abeyance and another has yet to take form. What happens during that lag? How does one represent not the social world itself but how that world is being seen now? That is the question Stein raises, and the question Jacob's Room pursues.

Most striking in Jacob's Room is the way Woolf includes the perspectives of so many characters, especially female and lowerclass characters, who inhabit Jacob's living space, a modern, urban space cluttered with people as well as objects. The point of view shifts so abruptly and frequently that Jacob is not so much refracted through myriad perspectives as he is, to employ Stein's analogy, assembled in time out of glimpses and inferences created by chance encounters. The narrative calls attention to the mediation of point of view. Mrs. Norman finds herself alone in a carriage with Jacob as both travel to Cambridge. Initially alarmed to be closeted with a young man, she quickly sums him up, based on his appearance, as "indifferent," "unconscious," "distinguished" - "like her own boy?" $(J R 3 \mathrm{I})$. The interrogative marks the shift in perspective to that of the narrating agency, who then undermines the reliability of Mrs. Norman's characterization: "One must do the best one can with her report" ( $J R R_{3}$ ). We must not only make do with the bits and pieces we can scrape together about Jacob, we must be aware of whose vision provides those details. Similarly Mrs. Papworth reports on Jacob and Bonamy's argument overheard from the scullery where she washes up the evening's dishes, getting Jacob's name wrong (she calls him Sanders) and failing to grasp their words: "objective something' $\ldots$ and 'common ground' and something else - all very long words" ( $J R$ IO2). Again, the mediation is emphasized: "and where an inquisitive old woman gets a name wrong, what chance is there that she will faithfully report an argument?" ( $J R$ IO2). In this novel, a grand generalization, "For he had grown to be a man and was about to be immersed in things," that sounds like the voice of an omniscient narrator is attributed to "the chambermaid "fingering [Jacob's] keys, studs, pencils, and bottles of tabloids strewn on the dressing-table" ( $J R$ I39) as she cleans his room. To be immersed in "things" means not abstractions and ideals, such as politics and patriotism, not housing and property, but ordinary objects. 
Explicitly in Jacob's Room, and implicitly in "Mr. Bennett and Mrs. Brown," Woolf explores the effects of urban mass culture on the structure of experience and on new formations of the subject. We stand on Mudie's corner in Oxford Street and see the omnibuses locked in traffic: "The proximity of the omnibuses gave the outside passengers an opportunity to stare into each other's faces" ( $\left.J R 6_{4}\right)$, a social relation unique to urban mass culture, as sociologist Georg Simmel had noted earlier. ${ }^{17}$ In telling the story of Jacob Flanders, Woolf seeks to steep us in that atmosphere, to capture and reproduce the sense modalities of modern urban life. As Woolf writes in "Mr. Bennett and Mrs. Brown," fiction has changed because social relations have changed. The cook now pops into the drawing room to borrow the daily paper. The city streets are now crowded with working women: Milly Edwards, the waitress; Nelly Jenkinson, the typist; Fanny Elmer, the artist's model. What kind of narrative perspective comes with that kind of change in social relations?

By way of an answer, let me turn to another passage in Jacob's Room. Describing the multitudes around St. Paul's, where Jacob is playing the tourist, the narrator writes:

Nothing could appear more certain from the steps of St. Paul's than that each person is miraculously provided with coat, skirt, and boots; an income; an object. Only Jacob, carrying in his hand Finlay's Byzantine Empire, which he had bought in Ludgate Hill, looked a little different; for in his hand he carried a book, which book he would at nine-thirty precisely, by his own fireside, open and study, as no one else of all these multitudes would do. They have no houses. The streets belong to them; the shops; the churches; theirs the innumerable desks; the stretched office lights; the vans are theirs, and the railway slung high above the street. If you look closer you will see that three elderly men at a little distance from each other run spiders along the pavement as if the street were their parlour, and here, against the wall, a woman stares at nothing, boot-laces extended, which she does not ask you to buy. The posters are theirs too; and the news on them. A town destroyed; a race won. A homeless people, circling beneath the sky whose blue or white is held off by a ceiling cloth of steel filings and horse dung shredded to dust. (JR 66)

"They have no houses" not because they are literally homeless but because the urban scene is the only place where we confront these 
modern subjects, the "multitudes." They can't be identified by their houses, like Bennett's Hilda Lessways, for we know them only in their urban setting. The phrase, "If you look closer," calls attention to a new perspective. Woolf's "if you look closer" implies no moral address to the reader; in its movement from distance to close-up, the narrative perspective is like a camera zooming in on an object. As Benjamin observes, "a different nature opens itself to the camera than opens to the naked eye - if only because an unconsciously penetrated space is substituted for a space consciously explored." 18 Woolf consciously (and self-consciously) explores this space not only to draw attention to the people of the street, and to new class relations, but to the narrative perspective itself and to the difference new forms of narrative and new technologies make to how we relate to our changed social environment. In Jacob's Room, the dizzying shifts in the angle of vision create a pervasive uncertainty in the novel, a narrative uncertainty that is usually interpreted as Woolf's belief that we can never know another. But such an interpretation overlooks the emphasis on mediation. The novel is not about Jacob's world so much as it immerses us in the materiality of the moment, the lag when the perceptual apparatus is catching up with new technology, new media, and new social relations.

O'Keeffe's remark that "nothing is less real than realism," like Woolf's remark that by "real" she does not mean "life-like" ("Bennett" 103), is not, then, a rejection of realism so much as an acknowledgment that the nineteenth-century realist aesthetic created a way of seeing the world that no longer conforms to the lived experience of modern life, a point echoed by all three novelists considered here. To see a skyscraper in a calla lily is to perceive the flower looming large, a mass of color and texture. As an objective correlative for O'Keeffe's emotional experience of the flower, the skyscraper dominates one's field of vision as the flower dominated O'Keeffe's, providing a perspective unavailable to previous generations. To say that O'Keeffe's flowers are not realistic would be to assume the perceptual apparatus remains unchanged from generation to generation. "The only thing that is different from one time to another is what is seen," Stein proclaims in "Composition as 
Explanation" (1926), "and what is seen depends upon how everybody is doing everything." "And in the modernist era, everybody is doing everything quickly. A skyscraper rises overnight; a motor car stirs up a "raging torrent" of impressions; the shutter of a lens captures its subject in a tenth of a second; a radio broadcast reaches the ears of thousands of listeners instantaneously. The twentieth century, Stein avers, is movement. The nineteenth-century writer could describe a building or display window in precise detail as if it stood before her because her perspective was static. The modernist's perception of the same building or window gives the impression of speed - blocks of color, glimpses of bits and pieces that never cohere into a picture. "[T]he only thing that is different [from generation to generation]," Stein insists, "is what is seen when it seems to be being seen, in other words, composition and time-sense." 20 "When it seems to be being seen" refers at once to the present moment in which the composition takes shape, and to the self-conscious awareness of its mediation, its "being seen." The drag upon the senses produced by old habits of seeing, that lag between what one is capable of seeing, or sensing, and what is "being seen" or felt is the substance of the modernist novel.

The modernist novel is about what happens in time, not just about a particular time. It works against the obliteration of the moment in the event. For, as Stein writes, "the novel which tells about what happens is of no interest to anybody." ${ }^{21}$ Not surprisingly, given her famed ego, but perhaps surprisingly given that Stein says the twentieth century is movement, Stein pronounced her novella "Melanctha," written in 1905 , "the first definite step away from the nineteenth century and into the twentieth century in literature," point echoed in Howard Finn's assessment of Three Lives as "the first truly modernist novel." "In "Melanctha," Stein developed what she termed the continual or continuous present, where the narrative moves so slowly and repeats itself so often, "a constant recurring and beginning" as Stein puts it, that it is as if time did not flow linearly, as if past, present, and future coexisted. Time in this novella is synchronous, not chronological, a "constellation" of moments, to borrow Benjamin's term. ${ }^{24}$ As Carl Van Vechten remarked in his 
introduction to the I933 edition of Three Lives, "its ["Melanctha's"] subject matter . . . is similar to the subject matter of the realists, Zola and Flaubert ... but so different is the treatment that any question of influence may be immediately dismissed." 25 Van Vechten attributes influence to Cézanne; Stein would later credit the film and the assembly line.

Yet for a modernist work, the novella is notably devoid of references to new technologies or descriptions of urban scenes. Confined to the small town of Bridgeport, the banalities of the everyday are reflected in the banalities of its language: "Melanctha took good care of her mother. She did everything that any woman could, she tended and soothed and helped her pale yellow mother, and she worked hard in every way to take care of her, and make her dying easy. ... Melanctha did everything that any woman could, and at last her mother died, and Melanctha had her buried." ${ }^{26}$ Mundane repetition is the rhythm of her writing. In its emphasis on language, however, in its disrupted syntax (which North has characterized as a modernist strategy of "linguistic mimicry and racial masquerade" ${ }^{27}$ ), and especially in its strings of modifiers repeated with infinitesimal differences, the novella mimics, even anticipates, the "endless repetition of the average" ${ }^{28}$ that structures not only the routine of everyday life but also the comic strip and the electronic message board and which, Ann Douglas notes, was "a trick fast becoming a cultural law." 29 "If much modernism is about human movement," Enda Duffy observes, "then speed itself becomes the very narrative heft of much modernist artistic production. ... In each high modernist experimental form, the death of distance is hidden in plain sight, and speed as a way of life, a way of living, and a way of being has come true." ${ }^{\circ}$ Even in such a low-tech novel as this, the speed of modern technologies alters, if not the pace of the novel, at least the writer's and readers' "experience of time and space." ${ }^{31}$ For the everyday, as Rita Felski notes, comprises not only the routines and rituals of daily life, but "forms of consciousness" emergent in those routines. ${ }^{32}$

"Melanctha" opens with a dead baby, an event presented so nonchalantly that any "realist' pathos" is undercut by the matterof-fact style: "The child though it was healthy after it was born, did 
not live long. ... Rose Johnson had liked the baby well enough and perhaps she just forgot it for awhile, anyway the child was dead and Rose and Sam her husband were very sorry but then these things came so often in the negro world in Bridgepoint, that they neither of them thought about it very long" (TL 85). Nor does the narrative. "The painful, difficult birth-into-death of the black Johnson baby," writes Marianne DeKoven, is "implicated in the disruption of traditional narrative," a metaphor, DeKoven says, "of a new story not yet quite ready to be written." ${ }^{33}$ Here again we have the notion of writing in the lag between the break-up of former perceptual habits and literary conventions, and the formation of new ones. Again and again the narrative describes Melanctha on the cusp of wisdom, in the moment of coming to understand: "she knew very early how to use her power as a woman, and yet Melanctha with all her inborn intense wisdom was really very ignorant of evil" (TL 95); "Sometimes she would almost go over, and then the strength in her of not really knowing, would stop the average man in his endeavor" (TL 96). What we get in this novella is not experience in retrospect but experience as it unfolds in time, in the moment of its coming to be seen, or sensed. What we get, as Stein would put it, is experience, not events.

For in "Melanctha," "nothing much happens," as Stein famously said of Ulysses. ${ }^{34}$ Melanctha "wanders" - Stein's opaque yet revealing verb - throughout the story, from home to home, lover to lover, job to job without ever leaving the confines of her small town: "She was really very safe with all the wandering,.... in these days of her attempted learning" ( $T L$ 97). She and her lover, Jefferson Campbell, talk endlessly, exhaustively, without really communicating: "I certainly do wonder, Miss Melanctha, if we know at all really what each other means by what we are always saying" (TL I28). Stein's achievement lies in the minute parsing of emotional and sensual experience as it unfolds in time. In Jacob's Room, nothing much happens either in that events that might be considered significant in Jacob's life - his first sexual encounter, his first employment, his death on the battlefield - happen "off camera," so to speak. In Larsen's Quicksand, a lot happens, and yet nothing much happens 
in that the structuring of events is so repetitious that while Helga Crane moves a lot, she goes nowhere. Where Woolf's novel depicts the emergence of the modern woman - from Clara Durront, "a virgin chained to a rock" ( $J R$ I23 $_{3}$, whose passions are still held fast in the arms of social convention, to Fanny and Florinda, who go about freely with men - Stein, like Larsen, presents the coming into consciousness of the modern woman herself through a protagonist who sometimes seems "like one kind of girl" and sometimes "like a girl that is all different" ( $T L \mathrm{I}_{3} 8$ ). The repetition that structures Stein's novel, the glacial pace of the narrative, captures (or to adopt Stein's locution, "really captures") the emotional and sensual life of the modern woman in the interval between the old and the new, between what women, especially black women, were in fiction and in life, and what they will be, in that moment before new social identities stabilize. "Melanctha Herbert was always losing what she had in wanting all the things she saw. Melanctha was always being left when she was not leaving others. ... Melanctha Herbert was always seeking rest and quiet, and always she could only find new ways to be in trouble" ( $T L$ 89). Helga Crane exactly. "If we cannot look back of Miss Stein and find a literary ancestor," Van Vechten states, "it is easy to look forward: a vast sea of writers seems to be swimming in the inspiration derived from this prose." 35 And Nella Larsen professed herself one of them.

In a 1928 letter to Stein, accompanying a copy of her first novel, Quicksand, Larsen wondered with many other readers how Stein came to write "Melanctha." Acknowledging she has read "Melanctha" many times, Larsen writes: "And always I get from it some new thing - a truly great story. I never cease to wonder how you came to write it and just why you and not some one of us should so accurately have caught the spirit of this race of mine." ${ }^{36}$ For all the "racial ventriloquism" 37 attributed to its prose style, what seems to have captivated Larsen in "Melanctha" was the way the novella moves, the repetition of scenes and phrases that captures the slow emergence of a restless desire without any goal or resolution. What North refers to as the "most objectionable" aspect of Stein's story, "its fixation on the sexual lives of its subjects, as if African-American 
characters are to be understood primarily in sensual terms, ${ }^{38}$ might just be what Larsen found so compelling, and what she found missing in so much African-American writing that either elided sexuality altogether in an effort of "racial uplift," or focused on the sensuality as a form of defiance. Larsen seems to have been attracted by the way Melanctha's sensuality is conveyed linguistically and structurally, appreciating how Stein has seized the interval, the moment of a black woman's emotional and sensual awakening that remains inchoate.

Quicksand shows its indebtedness to Stein's novella as much in its formal qualities as in its representation of race - repetition with variation, experience over event, free indirect discourse. Long read in terms of the "tragic mulatto" narrative tradition and the aesthetic debates of the Harlem Renaissance, more recent scholarship treats Larsen's Quicksand as a distinctly modernist novel. In her forward to Larsen's second novel, Passing (I929), Mae Henderson defines aesthetic modernism in terms of "aesthetic self-consciousness, stylistic fragmentation, and ... [a] questioning of representation" within the context of "a distinctively modern sense of dislocation and ambiguity." 39 To read Larsen's novel in the context of Stein's and Woolf's modernism is to highlight the way the novel expresses its contemporaneity both thematically and formally, to see the estrangement from realism in its apparently realistic style. Helga Crane represents not the confinement of identity by racial and sexual ideologies, as earlier readings emphasized, but, as Jeanne Scheper has argued, "the expansion of identity promised ... by geographic mobility." ${ }^{\circ}$ Helga's movements from one geographic location to another - to the north and then back south, across the Atlantic and then back home - like her desire to keep moving, are not an expression of the tragedy of having no home, no determinate race, but rather, Scheper claims, "a mobile performance of modern subjectivity." $4 \mathrm{I}$ Yet that promise of expansion is never realized; the novel ends not with a resolution but with the endless repetition of the same as Helga's monotonous cycle of childbirth begins for the fifth time.

Helga, who "could neither conform, nor be happy in her unconformity," ${ }^{42}$ continually finds contentment in some new place 
only to discover it cannot last, continually has the "sense of having come home" ( $Q \& P 43)$ only to realize there is no place for her: "She, Helga Crane, who had no home" (QESP 30 ). Home, with its comfort of familiar conventions and its connotations of stasis and permanency; does not fit the time-sense of the twentieth century as Stein has defined it. Instead, Helga conceptualizes herself as "moving shuttle-like from continent to continent" ( $\left.Q \mathcal{E} P 9^{6}\right)$. As North says of D. H. Lawrence, who spent almost the entire year of 1922 traveling around the world, one might say of Helga Crane: "the only place [she] finally belonged was in transit." ${ }^{43}$ The sense of being in transit need not represent spatial movement alone, but also the temporality of the interval, the synchronicity of the now.

The opening scene of the novel presents a tableau vivant of Helga "alone in her room," which the narrative describes as "a small oasis in a desert of darkness" (literally, the dark bodies of the faculty and students of Naxos, figuratively the darkness of her "not really knowing," like Melanctha) ( $Q \mathcal{E} P_{\mathrm{I}}$ ). "This little time" alone in her room marks a hiatus in the long, frustrating hours of teaching recalcitrant students. Helga uses "little time" later to refer to her mother's brief moment of passion "before that gay suave scoundrel, Helga's father, had left her" ( $Q \mathcal{E} P$ 23). The phrase "little time" captures the fleetingness of the interval. From the beginning, the narrative conveys a sense of restlessness without real movement as a discontented Helga chafes against the "strenuous rigidity of conduct" at this all-black college. And as in Jacob's Room, it is a framed moment, drawing our attention to its mediation: "An observer would have thought her well fitted to that framing of light and shade" ( $Q \mathcal{E} P$ 2). ("Would have thought" in the sense of, had there been anyone observing, but also had the observer been using outmoded perceptual equipment.) Framed moments recur in this novel, most notably in the vaudeville house where Helga, "an ironical and silently speculative spectator," watches the negro performers on stage in a "slavish imitation of traits not their own," performing a masquerade of blackness that stirs in her both revulsion and "urgent longings": "But she returned again and again" ( $Q \mathcal{E} P$ 82, 83). Or the revival scene that Helga watches in fascination and 
horror until, overcome with "weakness and nausea," she succumbs, "and in that moment she was lost - or saved" ( $Q \mathcal{E} P$ II3). Each of these framed scenes conveys the sense of being caught in a space between old forms and the possibility of something new that characterizes the time-sense of the modernist novel.

Quicksand is a quintessentially modernist novel in other, more familiar ways: its urban settings, its nightclub scenes, its references to jazz, its fashion sense. Larsen too immerses us in the everyday life of Chicago, New York City, Harlem, and Copenhagan: the crowded city streets, "swarming with people, merging into little eddies and disengaging themselves .... the myriad human beings pressing hurriedly on" ( $Q \mathcal{E} P 30$ ), the advertisements in the shop windows, the rush of taxi cabs, the oppressive noise and odor. Helga's clothing is described in meticulous detail, the fabric, color, and accoutrements of the modern woman's attire. Helga's aesthetic and literary tastes, like Larsen's, are modern. Helga has read Henrik Ibsen and Anatole France's "The Procurator of Judea," with its "superbly ironic ending" ( $Q \mathcal{E} P$ I32). Her room at Naxos is decorated with a "blue Chinese carpet," "oriental silk," a "shining brass bowl crowded with many-colored nasturtiums," and books with "bright covers" (QEP I).

But it is less in the "fabric of things," as Woolf describes the Edwardian novel, that Larsen's novel feels modernist than in Helga's, and the narrative's, self-conscious awareness of "being seen." Whether describing the teachers at Naxos, the swarming masses in Chicago, the Harlem social elite, or the rural Alabama folk, Larsen always makes us aware of the narrative perspective so that we are not just watching the scene before us but aware that we are watching, as in a movie. Larsen's use of free indirect discourse exposes Helga's mindfulness of her own position as an onlooker, of and apart from the scene, and leads the reader - as Woolf does more explicitly - to an acute awareness of mediation. Helga sees that everyone around her (and maybe the reader as well) looks at race as it has been seen, not in its being seen.

Take, for example, the most self-reflexive scene in the novel, Alex Olsen's portrait of Helga Crane. In Copenhagen Helga's exotic 
tastes and aesthetic sense come to define her, and not just the things she desires, as a fetishized commodity. Her aunt and uncle, delighted to have this rare specimen of Africa decorating their home, dress Helga in "batik dresses," "a leopard-skin coat," "turban-like hats," "feathers and furs" (Q\&P $P$ 74), clothing "selected or suggested" by Olsen, the artist who paints her portrait, which Helga describes as "some disgusting sensual creature with her features" ( $Q \mathcal{E} P$ 89). It is a modernist painting in the Picasso style, admired by artists and critics, disliked by the public, and one that, Helga insists, is not at all "like her" (QEP 89). Her vision of who she is mediated by that painting as it was earlier by the cabaret performance. Larsen, like Woolf, calls attention to the various forms of mediation that structure our sense of what is "life-like," drawing attention to "what is seen when it seems to be being seen." No wonder Helga doesn't recognize herself, for the modernist portrait is not of her, not "lifelike" in that way, as Woolf would say. Larsen realizes that the familiar themes of the Harlem Renaissance novel can never be the same after modernism, that she cannot portray black characters without awareness of how they have been mediated in modern art and culture. Helga doesn't recognize herself in any image in her cultural repertoire. That image repertoire is stable, but Helga, a modern woman, is on the move. "The tradition has always been that you may more or less describe the things that happen," writes Stein in "What Are Master-pieces" (1936), "but nowadays everybody all day long knows what is happening and so what is happening is not really interesting, one knows it by radios cinemas newspapers ... until what is happening does not really thrill any one .... The painter can no longer say that what he does is as the world looks to him because he cannot look at the world any more, it has been photographed too much and he has to say that he does something else." ${ }^{44}$ Larsen can no longer look at the world the same after reading Stein. The rejection of traditional realism, as Stein's statement reveals, is linked to the temporality of the moment and the heightened mediation of "what is happening" everyday.

Everyday life, then, provides more than the backdrop for the modernist novel or its thematic content; the everyday structures the 
very experience of being modern and shapes the form of modernist literary works. Modernist literary techniques not only reflect everyday life in the modern world, recreating, for example, the sensorial experience of motoring through London or the uncanny experience of hearing a voice divorced from a body. These literary devices also prepared readers to live, as Stein put it, their "contemporariness." "Each generation has to do with what you would call the daily life," Stein continues. "[The writer] is expressing the thing that is being expressed by everybody else in their daily lives. The thing you have to remember is that everybody lives a contemporary daily life. The writer lives it, too ...."45 Modernist writers drove motor cars and rode omnibuses, watched skyscrapers erected, and shopped in department stores, listened to the gramophone and radio, and attended the cinema and jazz clubs. New visual, aural, and corporeal experiences created new sensory perceptions, new forms of imagination, and new states of consciousness conveyed in the novelistic styles that we have come to call modernist. The practices of everyday life rendered explicit in the modernist novel structure the very emergence of the modern subject. In this way, the modernist novel taught its audience how to read the contemporary scene, even, one might say, how to be contemporary.

\section{Notes}

I. Anita Pollitzer, A Woman on Paper: Georgia O'Keeffe (New York: Simon \& Schuster Inc., 1988), 224.

2. Virginia Woolf, Orlando: A Biography (New York: Harcourt Brace Jovanovich, I928), 299.

3. Gertrude Stein, "How Writing Is Written," in The Gender of Modernism, ed. Bonnie Kime Scott (Bloomington: Indiana University Press, 1990), 489 . Subsequent references to this edition will be made parenthetically in the text ("How").

4. Roger Fry, "An Essay in Aesthetics," in Vision and Design (1909; repr. London: Pelican, I96I), 23-9.

5. Henry James, "The Art of Fiction," in Theory of Fiction: Henry James, ed. James E. Miller, Jr. (Lincoln: University of Nebraska Press, I972), 27-44.

6. Fredric Jameson, Postmodernism, or the Cultural Logic of Late Capitalism (Durham, NC: Duke University Press, 1991), 38-9. 
7. Andreas Huyssens, "Mapping the Postmodern," New German Critique 33 (Autumn I984): 17 .

8. Douglas Mao and Rebecca Walkowitz, "The New Modernist Studies," PMLA I23 (May 2008): 737-48.

9. Michael North, Reading 2922: A Return to the Scene of the Modern (New York: Oxford University Press, 1999), 29.

Io. Ibid., 139 .

II. Walter Benjamin, "The Work of Art in the Age of Mechanical Reproduction," in Illuminations: Essays and Reflections, ed. Hannah Arendt, trans. Harry Zohn (New York: Schocken Books, 1968), 236.

12. Virginia Woolf, Jacob's Room (New York: Harcourt Brace \& Company, 1922), 7. Subsequent references to this edition will be made parenthetically in the text $(J R)$.

13. On Walker Evans's "Work Shoes" (1929), see Jameson, Postmodernism, Io.

I4. Thomas Lawson, "Last Exit: Painting," Artforum 20, no. 2 (October 1981): 45 .

I5. Stein, "How Writing Is Written," 494.

16. Virginia Woolf, "Mr. Bennett and Mrs. Brown," in The Captain's Death Bed and Other Essays (New York: Harcourt, 1950), I12. Subsequent references to this edition will be made parenthetically in the text ("Bennett").

17. On Simmel, see Benjamin, "On Some Motifs in Baudelaire," in Illuminations: Essays and Reflections, ed. Hannah Arent, trans. Harry Zohn (New York: Schocken Books, 1968), I91.

I8. Benjamin, "The Work of Art," 236.

19. Gertrude Stein, "Composition as Explanation," in A Stein Reader, ed. Ulla E. Dydo (Evanston, IL: Northwestern University Press, 1993). 497.

20. Ibid., 495, emphasis added.

21. Gertrude Stein, "How Writing Is Written," 493.

22. Gertrude Stein, The Autobiography of Alice B. Toklas, qtd. in Michael North, The Dialect of Modernism: Race, Language, and Twentieth-Century Literature (New York: Oxford University Press, I994), 6r.

23. Howard Finn, "Writing Lives: Dorothy Richardson, May Sinclair, Gertrude Stein," in The Cambridge Companion to the Modernist Novel, ed. Morag Shiach (Cambridge University Press, 2007), 201.

24. Walter Benjamin, "On the Concept of History," in Selected Writings, eds. Marcus Bullock and Michael W. Jennings, vol. 4, 2938-1940 (Cambridge, MA: Belknap-Harvard University Press, 1996), sect. 17.

25. Carl Van Vechten, "Introduction" to Three Lives (Norfolk, CT: New Directions, 1933), ix-x. 
26. Gertrude Stein, Three Lives (1909; New York: Vintage Books, I936), I Io. Subsequent references to this edition will be made parenthetically in the text $(T L)$.

27. Michael North, The Dialect of Modernism: Race, Language, and Twentieth-Century Literature (New York: Oxford University Press, 1994), preface, n.p.

28. Ann Douglas, Terrible Honesty: Mongrel Manhattan in the 1920s (New York: Farrar, Straus and Giroux, 1995), 121.

29. Ibid.

30. Enda Duffy, The Speed Handbook: Velocity, Pleasure, Modernism (Durham, NC: Duke University Press, 2009), Io.

31. Mary Wilson, The Labors of Modernism: Domesticity, Servants, and Authorship in Modernist Fiction (Surry, UK: Ashgate, 2013), 7.

32. Rita Felski, Introduction to the special issue of New Literary History, "Everyday Life," 33 (Autumn 2002): 607.

33. Marianne DeKoven, Rich and Strange: Gender, History, Modernism (Princeton, NJ: Princeton University Press, I991), 79.

34. Stein, "How Writing Is Written," 493.

35. Van Vechten, "Introduction," $\mathrm{x}$.

36. Nella Larsen, letter to Gertrude Stein, February I, I928, Beinecke Rare Book and Manuscript Library, Yale University (YCAL 76, Box 21I, Folder 2278). My thanks to Lena Hill for bringing this letter to my attention.

37. North, Dialect, preface, n.p.

38. Ibid., 70.

39. Mae Henderson, Critical Forward to Nella Larson's Passing (New York: Random House, 2007), xix.

40. Jeanne Scheper, "The New Negro Flâneuse in Nella Larsen's Quicksand," African American Review 42 (September 2008): 679.

41. Ibid., 686.

42. Nella Larsen, Quicksand and Passing (New Brunswick, NJ: Rutgers University Press, 1988), 7. Subsequent references to this edition will be made parenthetically in the text $(Q \mathcal{E} P)$.

43. North, Reading 2922, 12.

44. Gertrude Stein, "What Are Master-pieces and Why Are There So Few of Them?" (1936), in The Gender of Modernism, ed. Bonnie Kime Scott (Bloomington: Indiana University Press, 1990), 497.

45. Stein, "How Writing Is Written," 488. 